\title{
Proficiency-Testing Scheme for Detection and Enumeration of Campylobacter in Poultry Meat
}

\section{Souad Ben Bari*, Marie Dangerville, Romain Le Neve, Abdelkader Boubetra and Anne Tirard}

Bureau Interprofessionnel d'Études Analytiques (BIPEA), Paris, France

*Corresponding Author: Souad Ben Bari, Bureau Interprofessionnel d'Études Analytiques (BIPEA), Paris, France. E-mail: sbenbari@bipea.org
Received: October 01, 2020

Published: November 18, 2020

(C) All rights are reserved by Souad Ben

Bari., et al.

\begin{abstract}
Main food-borne infections in Europe and in the world are caused by Campylobacter jejuni and Campylobacter coli, the two most involved species of Campylobacteria. This is why, in 2018, BIPEA (Bureau Interprofessionnel d'Etudes Analytiques) launched a new proficiency testing scheme (PTS) to detect and enumerate Campylobacter species in poultry meat samples.

This proficiency test can be schematized by three main steps: preparation of homogeneous and stable samples, analyses by laboratories applying reference methods (ISO 10272 part 1 and 2 [1,2]) and/or alternative methods and statistical treatment of the data according to ISO 13528 standard [3].

Taking part in a proficiency-testing scheme allows laboratories to assess their performance for these analyses and compare their results with those from other laboratories. Therefore, these tests are crucial for laboratories to meet international ISO 17025 standard requirements [4].
\end{abstract}

Keywords: Proficiency Test Schemes; Laboratory Performance; Microbiology; Campylobacter; Detection; Enumeration

\section{Introduction}

Campylobacter is considered to be the most common bacterial cause of human gastroenteritis worldwide [5] and expected to increase especially in Northern Europe due to consequence of climate changes [6]. Campylobacter is a genus of Gram-negative and Oxidase-positive bacteria, appears spiral-shaped, "S"-shaped, or curved rod-shaped and is able to move via unipolar or bipolar flagella [7].

Many studies have shown that consumption and handling of chicken can increase the risk of human diseases [8]. Laboratories are able to ensure their microbiological analyses performance on food stuffs by regular participation in proficiency-testing schemes.

This PTS allows laboratories to demonstrate the robustness of their results, to compare each other analytical data and protocols used and get recognition of their analytical procedures used for detection and enumeration of target microorganism.

\section{Materials and Methods}

Sample production and shipment

One of the crucial aspects for the implementation of a proficiency-test program is the production of homogeneous and stable samples.

For this PTS, each sample of poultry meat was spiked with a strain of Campylobacter in well-controlled proportions. Samples for the test of June 2018 were spiked with Campylobacter jejuni whereas samples of February and November 2019 tests were spiked with Campylobacter coli.

The homogeneity of samples was checked by experimental studies on 10 samples in duplicate taken randomly across a batch 
of samples whereas the stability of samples was verified by analysing 3 samples after two, four, nine and fifteen days in accordance with ISO 13528 standard.

Then, four samples were shipped at $-(24 \pm 6)^{\circ} \mathrm{C}$ to each laboratory participating in the test.

\section{Analyses by laboratories}

Laboratories analysed these samples by using alternatives and/ or references methods. ISO 10272-1 is a reference method used to detect Campylobacter and ISO 10272-2 to enumerate them.

Laboratories submit their analysis results via electronic reply forms. Participants can provide some further information in their reply forms such as the date of the analysis, method used, growth medium used and supplier of the used media.

Considering the stability of the product, laboratories have been asked to analyse samples as soon as possible after the reception and to submit their results three weeks after samples reception.

\section{Statistical treatments}

The statistical treatments of the quantitative returned results are carried out in accordance with ISO 13528 standard. The assigned values $\left(\mathrm{x}_{\mathrm{pt}}\right)$ are estimated from the robust mean of all the results, with data transformed in log, except incoherent values. The proficiency of each laboratory is evaluated thanks to tolerance values (TV) equal to twice the standard deviations $\left(\sigma_{\mathrm{pt}}\right)$.

The quantitative results ( $\mathrm{x}$ ) could be evaluated and classified through z-scores, where $\mathrm{z}=\frac{x-x_{p t}}{\sigma_{p t}}$ :

- $\quad$ For $\mathrm{z} \leq|2|$, the result is considered as satisfactory,

- For $|2|<\mathrm{z}<|3|$, the result is considered as questionable,

- $\quad$ For $z \geq|3|$, the result is considered as unsatisfactory.

The qualitative results could be evaluated as follows:

- If the microorganism is detected when the sample is spiked with the strain, the result is satisfactory,

- If the microorganism is not detected when the sample is not spiked with the strain, the result is satisfactory,

- In the case of false negatives or false positives, the results are incoherent.

\section{Results and Discussion}

Since June 2018, BIPEA organizes two regular tests per year for this PTS, gathering twenty laboratories.

The major statistical parameters for June 2018, February 2019 and November 2019 tests are shown in table 2 for enumeration and in table 3 for detection.

The results from homogeneity check of February 2019 test are shown graphically in figure 1 . The gap between the minimal and maximal values are lower than 0,5 CFU/g transformed in log, allowing to conclude that samples of this test are homogenous enough to meet the requirements of the test.-

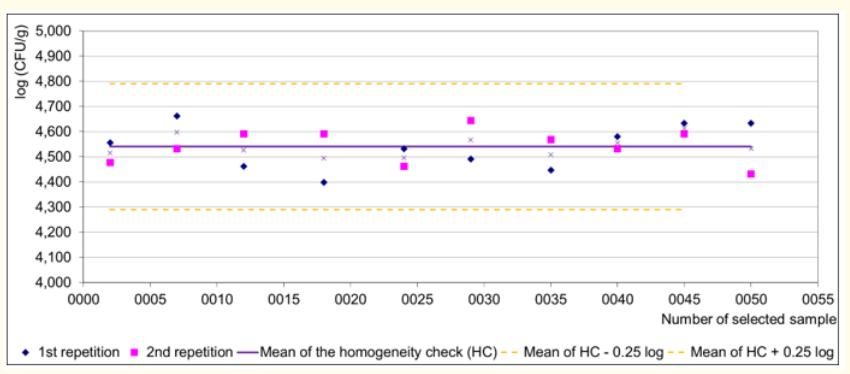

Figure 1: Results of the homogeneity check of the samples for the test of February 2019.

The results from stability checks after storing the samples at $(24$ $\pm 6)^{\circ} \mathrm{C}$ for 15 days after production show a satisfactory recovery rate (Table 1). The difference between the results collected from the second day $(D+2)$ to the last day of analysis $(D+15)$ can be explained by the variability of the performed method.

\begin{tabular}{|l|c|c|c|c|}
\hline Day of analysis & $\mathbf{D}+\mathbf{2}$ & $\mathbf{D}+\mathbf{4}$ & $\mathbf{D}+\mathbf{9}$ & $\mathbf{D}+\mathbf{1 5}$ \\
\cline { 1 - 4 } $\log (\mathbf{C F U} / \mathbf{g})$ & & & & \\
\hline Campylobacter jejuni & 5.78 & 5.75 & 5.42 & 5.29 \\
\hline Campylobacter coli & 5.80 & - & 5.55 & 5.37 \\
\hline
\end{tabular}

Table 1: Average results of Campylobacter enumeration in poultry meat sample after 15 days at $-(24 \pm 6)^{\circ} \mathrm{C}$.

The table 2 presents the statistical data for the tests of June 2018, February 2019 and November 2019 and shows an improvement of laboratories performance for the enumeration program since June 2018. 


\begin{tabular}{|c|c|c|c|}
\hline Tests & \multirow{2}{*}{$\begin{array}{l}\text { June } \\
2018\end{array}$} & \multirow{2}{*}{$\begin{array}{l}\text { February } \\
2019\end{array}$} & \multirow{2}{*}{$\begin{array}{l}\text { November } \\
2019\end{array}$} \\
\hline Statistical parameters & & & \\
\hline Number of returned results & 10 & 22 & 16 \\
\hline Assigned value $\left(\mathrm{x}_{\mathrm{pt}}\right)$ & 4.098 & 4.488 & 4.627 \\
\hline $\begin{array}{l}\text { Standard uncertainty of the } \\
\text { assigned value } u\left(x_{p t}\right)\end{array}$ & 0.296 & 0.123 & 0.200 \\
\hline $\begin{array}{l}\text { Robust standard deviation } \\
\mathrm{s}\left(\mathrm{x}_{\mathrm{pt}}\right.\end{array}$ & 0.670 & 0.311 & 0,578 \\
\hline $\begin{array}{l}\text { Number of results for the } \\
\text { assigned value } p\left(x_{p t}\right)\end{array}$ & 8 & 10 & 13 \\
\hline $\begin{array}{l}\text { Coefficient of variation }(\%) \\
\operatorname{CV}\left(x_{p t}\right)\end{array}$ & 16 & 7 & 10 \\
\hline $\begin{array}{l}\text { Standard deviation for pro- } \\
\text { ficiency assessment } \sigma_{p t}\end{array}$ & 0.670 & 0.311 & 0,578 \\
\hline Tolerance value (TV) & 1.340 & 0.622 & 1.156 \\
\hline Number of untrue results $p_{D}$ & 0 & 7 & 0 \\
\hline
\end{tabular}

Table 2: Summary of the statistical treatment of the data.

Indeed, less and less results are out of tolerance in this program and results from November 2019 test are all satisfactory. The number of results taken into account for assigned value estimation increased from 8 results in June 2018 to 13 in November 2019.

Moreover, the coefficient of variation (CV) is below $20 \%$ and was equal to $10 \%$ for the test of November 2019; this allows to conclude that samples are homogeneous and stable.

The laboratories' quantitative results are shown graphically on figure 2 and 3 . These figures are histograms, showing assigned value and tolerance interval on the $\mathrm{x}$-axis and the results of laboratories in different colours depending on the performed method on the y-axis.-

For the test of June 2018, 4 laboratories used the reference method and 5 laboratories alternative methods (Figure 2) whereas for the test of February 2019 (Figure 3), 7 laboratories used the reference method and 13 laboratories used alternative methods. It should be noted that there was no tendency depending on the method used.

The laboratories' qualitative results are shown in table 3. All the laboratories reported expected results, except one laboratory which returned a false negative for February 2019 test. Thus, results show that laboratories participating to this test master the detection of a target microorganism.

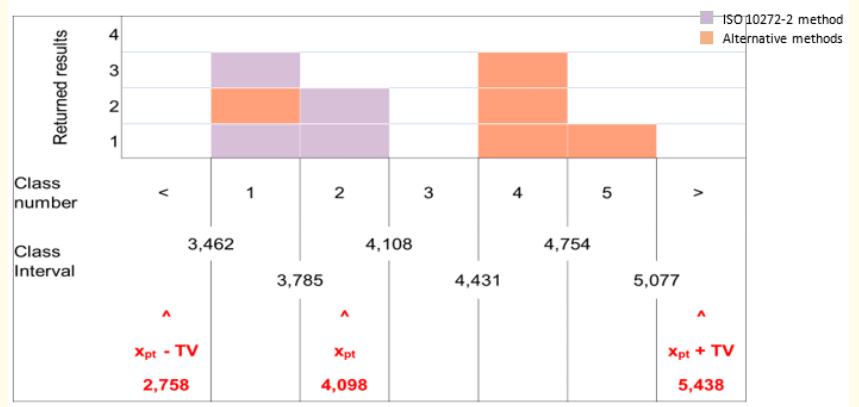

Figure 2: Distribution of Campylobacter enumeration results for June 2018 test.

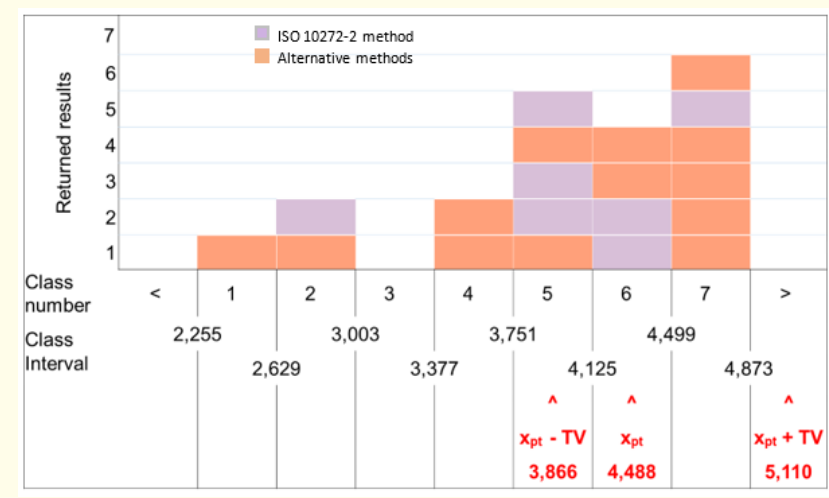

Figure 3: Distribution of Campylobacter enumeration results for February 2019 test.

\begin{tabular}{|c|c|c|c|c|}
\hline & & Sample 1 & Sample 2 & Sample 3 \\
\hline \multirow[b]{2}{*}{ June 2018} & Spiking & Spiked & Not spiked & Not spiked \\
\hline & Laboratory results & $\begin{array}{c}\text { Detected: } 9 \\
\text { Not detected :0 }\end{array}$ & $\begin{array}{c}\text { Detected: } 0 \\
\text { Not detected: } 9\end{array}$ & $\begin{array}{c}\text { Detected: } 0 \\
\text { Not detected: } 9\end{array}$ \\
\hline \multirow[b]{2}{*}{ February 2019} & Spiking & Not spiked & Not spiked & Spiked \\
\hline & Laboratory results & $\begin{array}{c}\text { Detected: } 17 \\
\text { Not detected: } 0\end{array}$ & $\begin{array}{c}\text { Detected: } 17 \\
\text { Not detected: } 0\end{array}$ & $\begin{array}{c}\text { Detected: } 18 \\
\text { Not detected: } 1\end{array}$ \\
\hline \multirow[b]{2}{*}{ November 2019} & Spiking & Not spiked & Not spiked & Spiked \\
\hline & Laboratory results & $\begin{array}{c}\text { Detected: } 0 \\
\text { Not detected: } 15\end{array}$ & $\begin{array}{c}\text { Detected: } 0 \\
\text { Not detected: } 15\end{array}$ & $\begin{array}{c}\text { Detected: } 15 \\
\text { Not detected: } 0\end{array}$ \\
\hline
\end{tabular}

Table 3: Summary of the qualitative results. 


\section{Conclusion}

This PTS allows laboratories to analyse Campylobacter specie on a real matrix of food stuffs (poultry meat). The results from laboratories for detection and enumeration of these bacteria have improved since the launch of this PTS. The number of results out of tolerance has decreased to none for the test of November 2019.

This PTS was successfully implemented and is a regular proficiency testing scheme with two tests per year. This program was approved and accredited by French accreditation body (COFRAC, Comité Français d'Accréditation).

Laboratories have now the possibility to demonstrate the robustness of their results, to compare each other analytical data and protocols used and get recognition of their analytical procedures by accreditation bodies for the detection and the enumeration of Campylobacter in poultry meat samples.

\section{Bibliography}

1. International standard: ISO 10272-1 - Microbiology of the food chain - Horizontal method for detection and enumeration of Campylobacter spp. - Part 1: Detection method.

2. International standard: ISO 10272-2 - Microbiology of the food chain - Horizontal method for detection and enumeration of Campylobacter spp. - Part 2: Colony-count technique.

3. International standard: ISO 13528:2015 - Statistical methods for use in proficiency testing by interlaboratory comparisons (2015).

4. International standard: ISO/IEC 17025:2005 - General requirements for the competence of testing and calibration laboratories (2005).

5. Naïtal M., et al. "Risques microbiologiques alimentaires" (2017): 461-480.

6. Kuhn K G., et al. "Campylobacter infections expected to increase due to climate change in Northern Europe". Scientific Report 10 (2020): 1-9.

7. Bourgeois CM., et al. "Microbiologie alimentaire: Aspect microbiologique de la sécurité et de la qualité des aliments". Tome 1 (1996): 82-88.

8. Luber P and Bartelt E. "Enumeration of Campylobacter spp on the surface and within chicken breast fillets". Journal of Applied Microbiology 102 (2006): 313-318.

\section{Assets from publication with us}

- Prompt Acknowledgement after receiving the article

- Thorough Double blinded peer review

- Rapid Publication

- Issue of Publication Certificate

- High visibility of your Published work

Website: https://www.actascientific.com/

Submit Article: https://www.actascientific.com/submission.php

Email us: editor@actascientific.com

Contact us: +919182824667 